\title{
5. The big stage: Australian women leading global change
}

\author{
Susan Harris Rimmer ${ }^{1}$
}

I am absolutely providing leadership when I provide a space for others to speak.

\section{- Caroline Lambert}

The founding mother of the Australian feminist internationalist movement must be Jessie Street (1889-1970). Street was a role model for all those who came after her, due to the way she saw the possibilities of using the international system in the fight against discrimination. A founder of the UN Commission for the Status of Women, amongst many other achievements, she had infinite energy as a campaigner.

This chapter assesses some of the contributions of Australian women who have been successful in promoting social change using international forums in the 30 years after Jessie Street's work, particularly at the United Nations. Their contribution has been profound, and often undervalued in broader Australian public life. Drawing on previous oral history interviews as well as new interviews (with Elizabeth Evatt, ${ }^{2}$ Hilary Charlesworth ${ }^{3}$ and Caroline Lambert ${ }^{4}$ ), I describe the different ways these women have displayed leadership for women's rights on the world stage. I ask how this social change agenda has benefited the Australian women's movement and affected the quality of Australian democracy.

This leads to the question of whether social change in Australia can and should be pursued through international processes, and/or whether international progress for gender equality without reform in Australia can be a goal in its own right. What is the measure of successful leadership in the international sphere? How can successful leadership translate into a contribution to Australian democracy?

\footnotetext{
1 The Australian National University. I am grateful for research assistance provided by Gillian Evans and for comments and leadership provided by Marian Sawer.

2 National Library of Australia Oral History, 'Interview of Elizabeth Evatt by Daniel Connell for the Law in Australia Project, 13 September 1996' (Canberra: National Library of Australia, Canberra).

3 National Library of Australia Oral History, 'Interview of Hilary Charlesworth by Susan Harris Rimmer for the Women's Leadership in a Century of Australian Democracy Project, 22 July 2011' (Canberra: National Library of Australia).

4 National Library of Australia Oral History, 'Interview of Caroline Lambert by Susan Harris Rimmer for the Women's Leadership in a Century of Australian Democracy Project, 11 November 2011' (Canberra: National Library of Australia).
} 
The United Nations is based on progressive ideals of peace, equality and human rights but it is as hierarchical and patriarchal as its constituent member states, ${ }^{5}$ and its processes can move at a glacial pace. Sometimes progressive ideas succumb to the lowest common denominator when consensus is required. Entry points and paths to influence are often difficult to detect. It is a space for global diplomacy, but is still dominated by highly educated, well-trained and usually male members of the foreign services.

The role most Australian women leaders have claimed in the international space has been that of 'expert' or a 'thought-leader'. In their chapter in this volume, Marian Sawer and Merrindahl Andrew explore the discomfort felt by feminists with traditional forms of leadership associated with hierarchy and the subordination of women. To influence international affairs is in many ways an elite sport, even as a representative of a non-governmental organisation (NGO). Deliberations in Geneva or New York feature extremely formal and often technical discussions and very clear hierarchies, with politicians and diplomats at the top. How can an international feminist exercise 'shared leadership' emphasising 'democratic process and consensus decision-making' in this context? Who is the constituency? Despite the elite character of multilateral work, in practice the women I studied usually worked in coalition, with a focus on inclusive process and a shared belief in the transformative power of gender equality across national boundaries.

What, then, is the relationship between international advocacy and the quality of Australian democracy? My argument is that domestic reform and engagement with the UN system or other international forums can be a mutually enriching experience. Like Jessie Street, these women have been innovative in their use of the international system or have created new ideas about international law and practice. Their experience has some common themes: the need for both patience and determination; the key role of good gender analysis as opposed to general gender awareness; and the importance of strategic thinking. The last can range from improving decision-making machinery in the interests of women to changing the way the reform agenda is formulated.

These stories of leadership at the international level need to be told, especially as the feminist movement in Australia undergoes generational change. Australian advocates for women's rights should consider using international processes as one of their tools but with full knowledge of the limits to achieving transformative change in this way. These experiences also need to be documented lest they be lost to history.

5 See further Hilary Charlesworth and Christine Chinkin, The Boundaries of International Law (Manchester: Manchester University Press, 2000). 


\section{The Hon. Elizabeth Evatt AC, AO: The judge}

Elizabeth Evatt has had a stellar career combining international and domestic work in pursuit of human rights, especially women's rights. ${ }^{6}$ Evatt was in some ways born into public life. She is the niece of $\mathrm{H}$. V. Evatt, deputy prime minister and president of the UN General Assembly in 1948. Her father, Clive Evatt, was made a King's Counsel at the age of thirty-five. Elizabeth was brilliant, too, and a prodigy, becoming the youngest student to study law and the first woman to win the Law Medal at the University of Sydney, before completing her masters at Harvard University in the United States. Evatt was appointed deputy president of the Australian Industrial Relations Commission in the 1970s, before becoming the first chief justice of the Family Court of Australia. Her term as chief justice was turbulent, and often dangerous, with attacks on judges and the court itself. ${ }^{7}$

From 1988 to 1993, she was president of the Australian Law Reform Commission and then chancellor of the University of Newcastle. Notably, she chaired the Royal Commission on Human Relations from 1974 to 1977, which dealt with a wide variety of sensitive social issues, such as abortion, contraception, sex education, family law and violence against women. The royal commission broadened official definitions of domestic violence to include emotional and verbal as well as physical abuse. ${ }^{8}$

In 1984, soon after the Commonwealth Sex Discrimination Act finally made it through parliament, Evatt was elected as an expert to the Committee on the Elimination of Discrimination against Women, the treaty body for the Convention for the Elimination of All forms of Discrimination against Women (CEDAW). ${ }^{9}$ Reportedly, when Anne Summers called Evatt to ask if she accepted the Government's support for her nomination, she was surprised and asked if the CEDAW Committee did anything 'useful'. Summers replied that the Government was nominating her precisely because they wanted CEDAW to do something useful. ${ }^{10}$ And so it came to pass. Between 1984 and 1992, Evatt was a member of the committee, serving as its chair from 1989 to 1991. She was then elected a member of the UN Human Rights Committee, from 1993 to 2000, which she

\footnotetext{
6 See further Susan Harris Rimmer, ‘Raising Women Up: Analysing Australian Advocacy for Women's Rights under International and Domestic Law', in Sex Discrimination in Uncertain Times, ed. Margaret Thornton (Canberra: ANU E Press, 2011).

7 Ruth Newsbury, 'A Battle-Scarred Judge Fights', The Advertiser [Adelaide], 10 June 1986: 29.

8 See further Marian Sawer, Making Women Count: A History of the Women's Electoral Lobby in Australia (Sydney: UNSW Press, 2008), 48.

9 United Nations Convention on the Elimination of All forms of Discrimination against Women, GA res. 34/180, 34 UN GAOR Supp. (No. 46) at 193, UN Doc. A/34/46; 1249 UNTS 13; 19 ILM 33 (New York: United Nations, 1980).

10 Peter Thomson, ‘Elizabeth Evatt: Integrating Women's Issues in the United Nations Human Rights System', in Australians at the United Nations, Unpublished ms (Canberra: Department of Foreign Affairs and Trade [on file with author], 1996), 4.
} 
combined with a role as a part-time commissioner of the Australian Human Rights and Equal Opportunity Commission (now the Australian Human Rights Commission), from 1995 to 1998. These simultaneous appointments exemplify Evatt's capacity to connect the international and the domestic spheres.

During her long terms with both the CEDAW and the human rights committees, Evatt embarked on a tireless agenda of procedural reform and succeeded, together with a group of like-minded committee members, in improving the quality of analysis of general comments, the structure and length of meetings, the reporting procedures and the breadth of subject matter of the committees. ${ }^{11}$ Such procedural reforms led to many substantive outcomes for women's rights, especially in the general recommendations on sexual stereotyping, incompatible reservations to the convention on the grounds of culture and religion, and female circumcision. The document she is best known for-General Recommendation 19, drafted in 1992-found that violence against women constituted discrimination. ${ }^{12}$

This was important because, notwithstanding the numerous strengths of CEDAW - including its extension to private actors and its aim to eliminate harmful customary practices ${ }^{13}$ - one of its most glaring shortcomings is the omission of violence from its terms. Under Evatt's direction, the CEDAW Committee endeavoured to rectify this deficiency through Recommendation 19, which specifies gender-based violence as a form of discrimination prohibited by the treaty. ${ }^{14}$ The adoption of the Declaration for the Elimination of All forms of Violence against Women by the UN General Assembly in 1993 also responded to this deficiency. ${ }^{15}$ This work has been the foundation of many global policies and much jurisprudence. Recommendation 19 and the declaration provide the conceptual basis for 'Outcome 5' of the 2009 report of the National Council to Reduce Violence against Women and their Children. ${ }^{16}$ This outcome encompasses strategies to strengthen legal responses to domestic violence, which sit within a wider social response - for example: Strategy 5.1, improve access to justice for women and their children; Strategy 5.2, strengthen leadership across justice systems; and Strategy 5.3, justice systems work better together and with other systems.

11 Ibid., 8-10.

12 Committee on the Elimination of All forms of Discrimination against Women, General Comment 19 on Article 16 (and Article 5), Violence Against Women, 29/01/92, A/47/38 (New York: United Nations).

13 See Articles 2 and 5. Traditionally, human rights law has only provided protection against governments rather than private actors.

14 Committee on the Elimination of All forms of Discrimination against Women, General Comment 19 on Article 16 (and Article 5).

15 United Nations General Assembly, Resolution 48/104 of 20 December 1993 (New York: United Nations, 1993).

16 National Council to Reduce Violence against Women and their Children, Time for Action: National Council's Plan for Australia to Reduce Violence against Women and Children 2009-2021 (Canberra, 2009). 
Evatt's work with the Human Rights Committee was equally groundbreaking working again on the compatibility of reservations to the International Covenant on Civil and Political Rights (ICCPR), contributing to drafting the controversial General Comments on Article 18 (freedom of religion) ${ }^{17}$ and drafting Article 25 (free elections and universal suffrage). ${ }^{18}$ She worked hard to realise the 'scope and potential' of the ICCPR's emphasis on the right to equality to be a 'powerful tool' to protect the rights of women in all fields, but found it a struggle. ${ }^{19}$ Many of her interventions on violence against women, rights in marriage and gendered forms of persecution in asylum claims appear, however, in the revised General Comment on Article 3 (equal rights of men and women) on which she worked closely with Professor Cecilia Medina of Chile. It was issued in March 2000. ${ }^{20}$

Elizabeth Evatt's vision of human rights is ultimately a unifying one. Her particular genius is the ability to look beyond artificial legal boundaries and examine legal instruments from the stand point of the holistic and lived experience of an affected person, and then to translate this view into impeccably logical, analytically rigorous and technically accurate legal discourse. She sees life in all its messiness, but renders it in judicial prose. When you read the general recommendations and comments she drafted, they sound so much like shining good sense, it is hard to remember how groundbreaking and controversial they were at the time, and how much Evatt had to invest in procedural reform for long periods to realise the opportunity to produce the documents in a collective and empowering manner.

Evatt's work for human rights certainly did not end with her time at the United Nations, ${ }^{21}$ but my argument is that just as her international work was influenced by her domestic experience, so too has that international dimension added richness and weight to domestic advocacy - her own and that of the many of us influenced by her. Evatt sees her work as a form of activism, ${ }^{22}$ and she is

17 Human Rights Committee, General Comment 22, Article 18 (Forty-Eighth Session, 1993), UN Doc. CCPR/C/21/Rev. 1/Add. 4 (1993), Reprinted in Compilation of General Comments and General Recommendations Adopted by Human Rights Treaty Bodies, UN Doc. HRI/GEN/1/Rev 6 (New York: United Nations, 2003), 155. 18 Human Rights Committee, General Comment 25, The Right to Participate in Public Affairs, Voting Rights and the Right of Equal Access to Public Service (Article 25), (Fifty-Seventh Session, 1996), UN Doc. CCPR/C/21/ Rev. 1/Add. 7 (1996), Reprinted in Compilation of General Comments and General Recommendations Adopted by Human Rights Treaty Bodies (New York: United Nations, 2003), 168.

19 Thomson, 'Elizabeth Evatt', 19.

20 Human Rights Committee, General Comment 28, Equality of Rights between Men and Women (Article 3), (Sixty-Eighth Session, 2000), UN Doc. CCPR/C/21/Rev. 1/Add. 10 (2000), Reprinted in Compilation of General Comments and General Recommendations Adopted by Human Rights Treaty Bodies (New York: United Nations, 2003), 179.

21 Evatt was a judge of the World Bank Administrative Tribunal, a visiting professor at the University of New South Wales and chair of the board of the Public Interest Advocacy Centre in Sydney. She has for many years been a member of the Australian section of the International Commission of Jurists and was elected as a commissioner in April 2003. She has made valuable contributions to the public debate in recent years on sedition laws, the treatment of asylum-seekers and the need for an Australian Human Rights Act.

22 Kay O'Sullivan, Trailblazers: The Road to Equality (Melbourne: Australia Postal Corporation, 2011 ), 32. 
passionate about holding the United Nations to account for upholding human rights and gender equality. ${ }^{23}$ Her distinctive brand of leadership may stem from the fact that she often sounds like simply the smartest and most decent person in the room. Professor Hilary Charlesworth, discussed below, describes her as a role model in three words: 'brilliance, energy and commitment.'

Evatt has won the Human Rights Medal amongst many other accolades, and last year was captured as an 'Australian Legend' on a postage stamp. When asked about her theory of leadership, however, she snorted down the phone: 'I just get on with it!' She is very modest about her own role and achievements. Despite, or perhaps because of, her illustrious career, she is today often despondent and critical about human rights issues in Australia and around the globe. ${ }^{24}$

\section{Professor Hilary Charlesworth: The academic/ activist}

Hilary Charlesworth has achieved global renown for her academic work on feminist approaches to international law. She has been a commissioner for the Australian Law Reform Commission, and was appointed by Australia as a judge to the International Court of Justice for the whaling case in 2011. As a member of a large Melbourne academic family, Hilary, like Elizabeth Evatt, excelled at the University of Melbourne and undertook her doctorate at Harvard University. Professor Charlesworth was given a chair at the University of Adelaide Law School at age thirty-eight. She then came to The Australian National University and has built an international reputation as a jurist.

In 2013, Charlesworth was professor and director of the Centre for International Governance and Justice in the Regulatory Institutions Network at The Australian National University and also holds an appointment as Professor of International Law and Human Rights. She has held visiting appointments at US and European universities. She held an Australian Research Council (ARC) Federation Fellowship from 2005 to 2010 and then an ARC Laureate Fellowship. She was president of the Australian and New Zealand Society of International Law (1997-2001). She is on the editorial boards of a number of international law journals and served as co-editor of the Australian Yearbook of International Law from 1996 to 2006 and a member of the Board of Editors of the American Journal of International Law, 1999-2009. She was joint winner of the American

23 Rosemary West, 'Judging Women's Place in the World', The Age, 10 May 1995, 21.

24 Elizabeth Evatt, 'Falling Short on Women's Rights: Mis-Matches between SDA and the International Regime', in Human Rights 2004: The Year in Review, ed. Marius Smith (Melbourne: Castan Centre for Human Rights Law, Monash University, 2005). 
Society of International Law's 2006 Goler T. Butcher Medal in recognition of 'outstanding contributions to the development or effective realization of international human rights law'. ${ }^{25}$

Professor Charlesworth has a strong activist streak combined with academic achievement. She led a group of international lawyers to write a public letter in February 2004 challenging the legality of the invasion of Iraq under international law. ${ }^{26}$ She has worked with various non-governmental human rights organisations on ways to implement international human rights standards and was chair of the ACT Government's inquiry into an ACT Bill of Rights, which led to the adoption of the ACT Human Rights Act 2004- the first such legislation in Australia. She has been working hard to have economic, social and cultural rights included in the Act, which would also be an Australian first.

Like Evatt, Charlesworth emphasises collegiality and collaboration as important to her success. She gives great weight to the 'wonderful richness' and support of a cohort of female and male colleagues throughout her career, especially her writing partner, Christine Chinkin from the London School of Economics, Mary Wood, Andrew Byrnes and John Braithwaite. She notes how much she has benefited from the generosity of mentors, particularly international lawyers Philip Alston and James Crawford.

Although an acknowledged trailblazer, Charlesworth in her National Library of Australia interview, describes her most seminal article as a partial failure or disappointment, because she hoped the mainstream international law discipline would engage and respond to the arguments, and thus far it has not. ${ }^{27}$ She celebrates the fact, however, that this work did create space for feminist inquiry. She looks back with most pride on her teaching career and the progress of her students.

When asked to describe women's leadership and social change in the international space, Charlesworth nominates Elizabeth Evatt; Jessie Street; the head of UN Women (2010-13), Michelle Bachelet from Chile, who was once a refugee in Australia; Penny Wensley, Australia's Ambassador to the United Nations and Governor of Queensland from 2008; and Erika Feller, Assistant High Commissioner of the UN Refugee Agency. Of Feller, Charlesworth notes she is a gifted diplomat who will often speak plainly and with strength-excellent Australian characteristics.

25 See: American Society of International Law, Awards and Honours. http://www.asil.org/about/awardsand-honors.

26 Hilary Charlesworth, 'Saddam Hussein: My Part in His Downfall', Wisconsin International Law Journal 23 (2005): 127-43.

27 Hilary Charlesworth, 'Talking to Ourselves? Feminist Scholarship in International Law', in Feminist Perspectives on Contemporary International Law, eds Sari Kouva and Zoe Pearson (Oxford: Hart Publishing, 2011), 17-32. 
Charlesworth identified the following values in a leader: resilience, graciousness, humanity, integrity and inspiration. She felt the most admirable women leaders of her experience had certain common methods: they were consultative and approachable, they found consensus if possible, they did not shirk from taking decisions and acting firmly, they weathered scrutiny and criticism, and they had a rich life outside work. She felt senior women leaders were scrutinised more closely, especially for any sign of excess emotion. In opposition, a 'lone wolf' hyper-masculinist style, sometimes adopted by women, meant taking a position and crashing through. This may lead to a reputation for being strong, but meant a leader was unable to deepen their vision and learn. Above all, Professor Charlesworth's style of leadership is by elegant example.

Charlesworth and Evatt as judges and academic experts work within a hierarchy and leave a clear paper trail of their work, even if their own humility and belief in collaboration mean that certain aspects of their leadership may go unrecorded. But what happens if a leader in international reforms for gender equality chooses to work from a civil society position?

\section{Dr Caroline Lambert: The civil society champion}

Caroline Lambert has been an advocate for women's economic and social rights at the United Nations, a leader in the Australian women's sector heading many shadow reporting processes for UN treaties ${ }^{28}$ and, from 2007, the executive director of the YWCA Australia. Over a 25-year period, she has been involved in a range of community organisations and co-founded (with Barbara Palmer) the Women's Rights Action Network Australia in 1998. She was involved with Amnesty International for many years, and is a past chair of Women's Housing Limited in Victoria. Lambert has a $\mathrm{PhD}$ on women, trade, human rights and liberal economic and political theory. She is the co-author of Critical Chatter: Women and Human Rights Activism in South East Asia and co-edited Global Issues, Women and Justice with Sharon Pickering. She was awarded a Women's Electoral Lobby Vida Goldstein Award for Human Rights in 2002. Of the research subjects, Dr Lambert was the youngest and has a thoughtful view of a feminist leadership style when pursuing national and global change, which takes a deliberate capacity-building approach.

Lambert says she is 'interested in ensuring that the voices of women in Australia, in particular young women's voices, are integrated in the policy process - so that policy can meet their needs and enable girls and young women in Australia to thrive and meet their full potential'. She works with a range of policy tools,

28 YWCA Australia and Women's Legal Services Australia, Australian NGO Shadow Report on the Implementation of CEDAW (2009). 
with a particular expertise in using the UN Human Rights Treaty System, to achieve domestic political change. The CEDAW requires participating countries, including Australia, to put in place legal, policy and financial measures to protect women from discrimination and to uphold their rights. Participating countries must also report to the UN CEDAW Committee about their actions. Australia was last reviewed in July 2010, and before that in 2006.

From 2008 to 2011, YWCA Australia was the lead agency on an Australian Government contract to develop a CEDAW Shadow Report, an Aboriginal and Torres Strait Islander Women's CEDAW Shadow Report, and follow-up materials. YWCA Australia under Lambert's direction worked with Women's Legal Services New South Wales and Kingsford Legal Centre on the project. In 2012, YWCA Australia developed and launched the CEDAW Action Plan for Women in Australia. The CEDAW Action Plan highlights 15 points that the Australian Government, and State and Territory governments, must work towards in responding to the international community's concerns about the human rights of Australian women. The CEDAW Committee conducted an interim review of Australia in 2012, and a periodic review in 2014.

The approach taken by Lambert to the creation of shadow reports on the Beijing Platform for Action has been one of 'community development'. She believes it is important for feminist activists to challenge hierarchies, making the case that community voices are just as valid as 'expert' voices. She believes that bringing local stories and a community activist approach can have significant impacts on conversations in Geneva and New York-using examples of the Optional Protocol to CEDAW, or having kinship language included at the Commission for the Status of Women, or having women's housing recognised by the then Commission on Human Rights.

She describes herself as 'not an up-front power person'; she tries to exercise mindful leadership through inquiry and collaboration. Her style is based on inquiry, moderation and questioning; she thinks this was initially due partly to lack of confidence in her own voice, but partly to ideological commitment to questioning power and hierarchy. Her style has not necessarily changed but her confidence has grown since becoming the executive director of the YWCA in 2006. She celebrates the history of the YWCA - its brand and traditions are strong.

When asked about the disadvantages of this type of intentional feminist leadership style, she nominated invisibility. She noted that media is fundamentally about conflict and a 'name'. Many feminist spokespeople like Germaine Greer are known for controversy and a highly individualistic style. If an organisation does not heavily promote a front person, good work can be hidden from a wider audience. A flat structure and commitment to consultation can mean the 
organisation is slower off the mark in responding to media or that it chooses to refer media and opportunities to other women's groups. Lambert believes that to achieve social change, it is better to be in collaboration with government as a constructive or critical friend, but be prepared to name where governments are falling short of their obligations. Media, on the other hand, is fundamentally about conflict. She has been learning to step into conflict, and to trust that hard conversations can lead to better outcomes. She states, however, that 'I am absolutely providing leadership when I provide a space for others to speak'.

When asked who her leadership role models were, she nominated a collective group of inspiring figures, which makes sense for someone who prizes a collective style. The group includes members of Lambert's family, Desmond Tutu and Nelson Mandela, Kate Gilmore from Amnesty International, Ann Walker from the Tribune Centre in New York, colleagues from the Women's Rights Action Network of Australia (WRANA) and YWCA colleagues, as well as collaborators Edwina McDonald and Emily Chew.

She admired Mary Robinson but finds her stature overwhelming, as international figures 'live at a speed' she chooses not to. She also identified Australian Labor Party (ALP) politicians Tanya Plibersek, Claire Moore and Margaret Reynolds for being willing to stand up to the system and make space for others and support their voice.

In many ways the distinctions I have made between these three women are exaggerated. Dr Lambert is also an expert author and the head of a substantial organisation, so the lines between my three subjects are blurry.

\section{Lessons learnt}

I implore feminist leaders not to confuse humility with obscurity. The next generation of women needs to know stories of reform and progress and career paths to follow, so please document and share (with due modesty if you must). There are other Australian women leaders on the world stage who deserve whole books to themselves, or whole shelves of books. I would nominate Erika Feller, top UN leader; Helen Caldicott, antinuclear activist; ${ }^{29}$ Stella Cornelius, champion of peace and conflict resolution; and Elizabeth Reid, international development pioneer. There is not enough on the record about Australian political figures who have used their role as parliamentarians to further social change for women in the international sphere, such as Margaret Reynolds, Janelle Saffin, Meredith Burgmann and Claire Moore.

29 See further Helen Caldicott, A Passionate Life (Sydney: Random House, 1996). 
There are several other lessons that might be learned from looking closely at leadership in the international context. If Australians are to continue to have an impact on the world stage they need government support but also to remain independent and respected at home for their expertise. Generally speaking, most of the advocates I have researched have not seen their international and domestic work as disconnected, but instead as mutually reinforcing.

Second, collaboration between political leaders and advisers with gender expertise can be a winning combination for women's rights at both domestic and international levels, and this is a rare commodity. Helen L'Orange and Neville Wran, Anne Summers, Geoffrey Yeend and Paul Keating, Susan Ryan and Mike Codd, Margaret Reynolds and Bob Hawke, Gough Whitlam and Elizabeth Reid, and Hilary Charlesworth and Jon Stanhope are all good examples of leadership in different roles that respected the expertise involved in good gender analysis. These collaborations have led to Australian leadership in the international sphere, and better policy at home. ${ }^{30}$ In this way Australian political leaders have opened up democratic space for the female half of the population underrepresented in almost all key decision-making areas of public life.

We need to have this expertise and leadership represented overseas in international forums where possible in order to help women in other societies and receive insights that can benefit women in Australia. The biographical lens employed in this chapter underscores that necessity. At the Commission for the Status of Women in 2009, Australia finally provided financial support for a representative of Indigenous women in its official delegation, Lesley Slalem. Australia was successful in nominating lawyer Megan Davis for election to the Permanent Forum of Indigenous Peoples in 2011. Australia did not, however, nominate a candidate in 2010 for the CEDAW Committee, despite the noted international expertise of several Australians, not least Andrew Byrnes, Dianne Otto and Hilary Charlesworth.

Leadership must come from many levels for international engagement to strengthen Australian democracy. Government support for Australian NGOs to engage with the UN human rights system is extremely limited and ad hoc. Learning the complex procedures of the UN system takes training, financial support and patience. Often the rewards come after many years of intricate drafting and procedural discussions. Australian NGOs could have that expertise, but usually it resides in one or two individuals like Caroline Lambert, often with little capacity or support for reporting back on international developments. A more systematic and long-term approach for NGO representation based on

30 Anne Summers notes that the 'femocrats had to fight and wheedle just like any other bureaucrat, even if their political masters were perhaps at times more sympathetic than other political leaders at different times'. Personal communication with author, 24 February 2010. 
a community engagement approach like that displayed by the YWCA would improve the overall quality of Australia's engagement with the United Nations. ${ }^{31}$ Another such group the Government should support is Women With Disabilities Australia (WWDA). ${ }^{32}$

Third, procedural reform is important and fundamental to substantive gains. Process matters to gender outcomes. General human rights machinery is still not in place, therefore women's rights always require an extra struggle. The uneven history of Australia's ratification of CEDAW and its Optional Protocol, considered alongside the rocky passage of the Sex Discrimination Act, is testament to this fact.

Elizabeth Evatt would say we still have much further to travel in making the rights of women part of the central project of protecting human rights in Australia, and simply achieving a Human Rights Act will also not be enough, if her experience with the ICCPR is any guide. ${ }^{33}$ Many other current issues speak of lack of motivation and commitment, a partial and narrow national imagination and a paucity of use of existing evidence for gender analysis when it comes to really valuing Australian women, recognising their dignity and fulfilling their rights.

If we take Evatt's human rights test of whether Australia is committed to 'raise from the lowest level those whose needs are greatest', I am not convinced Australia's parliamentary legislative process, bureaucratic machinery, political debate or data and evaluation methods are designed with that aim in mind. The United Nations has often been more resistant to reform than it should be according to its own charter. The experience of our heroines in this story of raising women up shows that progress will be slow, but possible. It just takes brilliance, energy and commitment. And getting on with it.

31 Australian women engaging with the United Nations include: Carolyn Hannan, Pene Mathew, Jane McAdam, Linda Bartolomei, Margaret Bearlin, Quentin Bryce, Gabrielle Cullen, Megan Davis, Anne-Marie Devereux, Alice Edwards, Louise Hand, Ellen Hansen, Lee Kerr, Caroline Lambert, Eve Lester, Libby Lloyd, Caroline Millar, Robyn Moody, Annie Petit, Margaret Reynolds, Ariane Rummery, Eileen Pittaway, Carole Shaw, Leanne Smith, Rosalind Strong, Irene Watson, Felicity Hill, Pera Wells, Penny Wensley, Margaret Callahan, Janet Hunt, Donelle Wheeler, Natasha Yacoub, Sarah McCosker, Letitia Anderson, Kirsten Hagon, Pene Mathew, Miranda Sisson and many more.

32 See further Marian Sawer: 'At the international level, WWDA was able to take part in the decade of negotiations over the UN Convention on the Rights of Persons with Disabilities along with representatives of other disability peaks. Thanks to this presence on the ground, WWDA contributed to the historic achievement of Article 6, which addressed the multiple discrimination experienced by women and girls with disabilities and Article 16, which recognised and required policy and legislative responses to the gender-based aspects of violence and abuse. This achievement was despite the opposition of the Australian government to the inclusion of an article on women in the Convention.' Marian Sawer and Merrindahl Andrew 'Hiding in Plain Sight', in The Women's Movement in Protest, Institutions and the Internet: Australia in Transnational Perspective eds Sarah Maddison and Marian Sawer (New York: Routledge, 2013), 78.

33 The Rudd Government rejected the recommendation for federal human rights legislation in April 2010 and said the decision would not be reviewed until 2014. 


\section{References}

Australian Human Rights Commission and the Australian Government Office for Women. Women of the World: Know Your International Human Rights. Canberra: Government of Australia, 2008.

Caldicott, Helen. A Passionate Life. Sydney: Random House, 1996.

Committee on the Elimination of All forms of Discrimination against Women. General Comment 19 on Article 16 (and Article 5). Violence Against Women. 29/01/92, A/47/38. New York: United Nations.

Committee on the Elimination of All forms of Discrimination against Women. Consideration of Australia's Combined 4th and 5th Report. New York: United Nations, 2006.

Committee on the Elimination of All forms of Discrimination against Women. Consideration of Reports Submitted by States Parties under Article 18 of the Convention on the Elimination of All forms of Discrimination against Women. Combined Sixth and Seventh Periodic Reports of States Parties: Australia, CEDAW/C/AUL/7. New York: United Nations, 9 March 2009.

Committee on the Elimination of Discrimination against Women. Forty-Sixth Session Summary Record of the 935th Meeting. New York, on Tuesday, 20 July 2010, at 10 a.m. CEDAW/C/SR.935. New York: United Nations, 2010.

Charlesworth, Hilary. 'Australia's Relations with the United Nations in the Post Cold War Environment.' Australian Federal Parliament, Joint Standing Committee on Foreign Affairs, Defence and Trade. Joint Committee Hansard, 21 March 2001, 429.

Charlesworth, Hilary. 'International Law: A Discipline of Crisis.' Modern Law Review 65 (2002): 377.

Charlesworth, Hilary. 'Saddam Hussein: My Part in His Downfall.' Wisconsin International Law Journal 23 (2005): 127-43.

Charlesworth, Hilary. 'Inside/Outside: Feminist International Legal Studies and Thirty Years of the CEDAW Convention.' Paper delivered at the Asian Society of International Law Conference, Tokyo, August 2009.

Charlesworth, Hilary. 'Talking to Ourselves? Feminist Scholarship in International Law.' In Feminist Perspectives on Contemporary International Law, edited by Sari Kouva and Zoe Pearson, 17-32. Oxford: Hart Publishing, 2011. 
Charlesworth, Hilary and Sara Charlesworth. 'The Sex Discrimination Act and International Law.' University of New South Wales Law Journal 27 (2004): 858.

Charlesworth, Hilary and Christine Chinkin. The Boundaries of International Law. Manchester: Manchester University Press, 2000.

Charlesworth, Hilary, Madeline Chiam, Devika Hovell and George Williams. No Country is an Island: Australia and International Law. Sydney: UNSW Press, 2006.

Cusack, Simone. 'Discrimination against Women: Combating its Compounded and Systemic Forms.' Alternative Law Journal 34(2) (2009): 86.

Declaration on the Elimination of All forms of Violence against Women. A/ RES/48/104. New York: United Nations.

Downer, Alexander, Daryl Williams and Phillip Ruddock. 'Improving the Effectiveness of United Nations Committees.' Joint media release, Parliament House, Canberra, 29 August 2000.

Edwards, Alice. 'Violence against Women as Sex Discrimination: Judging the Jurisprudence of the United Nations Human Rights Treaty Bodies.' Texas Journal of Women \& the Law 18 (2008): 1.

Evatt, Elizabeth. 'Falling Short on Women's Rights: Mis-Matches between SDA and the International Regime.' In Human Rights 2004: The Year in Review, edited by Marius Smith. Melbourne: Castan Centre for Human Rights Law, Monash University, 2005.

Gardam, Judith and Michelle Jarvis. Women, Armed Conflict and International Law. The Hague: Kluwer Law International, 2001.

Harris Rimmer, Susan. 'Grand Plans.' In Capturing the Year 2009: Writings from the ANU College of Asia and the Pacific, edited by Barbara Nelson and Andrew MacIntyre. Canberra: The Australian National University, 2009.

Harris Rimmer, Susan. 'Raising Women Up: Analysing Australian Advocacy for Women's Rights under International and Domestic Law.' In Sex Discrimination in Uncertain Times, edited by Margaret Thornton. Canberra: ANU E Press, 2011.

Human Rights Committee. General Comment 22, Article 18 (Forty-Eighth Session, 1993). UN Doc. CCPR/C/21/Rev. 1/Add. 4 (1993). Reprinted in Compilation of General Comments and General Recommendations Adopted by Human Rights Treaty Bodies. UN Doc. HRI/GEN/1/Rev. 6 at 155. New York: United Nations, 2003. 
Human Rights Committee. General Comment 25, The Right to Participate in Public Affairs, Voting Rights and the Right of Equal Access to Public Service (Art 25) (Fifty-Seventh Session, 1996). UN Doc. CCPR/C/21/Rev. 1/Add. 7 (1996). Reprinted in Compilation of General Comments and General Recommendations Adopted by Human Rights Treaty Bodies. UN Doc. HRI/GEN/1/Rev. 6 at 168. New York: United Nations, 2003.

Human Rights Committee. General Comment 28, Equality of Rights between Men and Women (Article 3) (Sixty-Eighth Session, 2000). UN Doc. CCPR/C/21/Rev. 1/Add. 10 (2000). Reprinted in Compilation of General Comments and General Recommendations Adopted by Human Rights Treaty Bodies. UN Doc. HRI/ GEN/1/Rev. 6 at 179. New York: United Nations, 2003.

Lambert, Caroline. 'Reproducing Discrimination: Promoting the Equal Sharing of Caring Work in CEDAW, at the ILO and in the SDA.' In Sex Discrimination in Uncertain Times, edited by Margaret Thornton. Canberra: ANU E Press, 2011.

Lambert, Caroline, Sharon Pickering and Christine Adler. Critical Chatter: Women and Human Rights Activism in South East Asia. Durham, NC: Carolina Academic Press, 2003.

L'Orange, Helen. 'Statement of Helen L'Orange, Leader of the Australian Delegation to the 33rd Session of the Commission for the Status of Women.' Vienna, March-April 1989.

National Council to Reduce Violence against Women and their Children. Time for Action: National Council's Plan for Australia to Reduce Violence against Women and Children 2009-2021. Canberra, 2009.

National Library of Australia Oral History. 'Interview of Elizabeth Evatt by Daniel Connell for the Law in Australia Project, 13 September 1996.' Canberra: National Library of Australia.

National Library of Australia Oral History. 'Interview of Hilary Charlesworth by Susan Harris Rimmer for the Women's Leadership in a Century of Australian Democracy Project, 22 July 2011.' Canberra: National Library of Australia.

National Library of Australia Oral History. 'Interview of Caroline Lambert by Susan Harris Rimmer for the Women's Leadership in a Century of Australian Democracy Project, 11 November 2011.' Canberra: National Library of Australia.

Newsbury, Ruth. 'A Battle-Scarred Judge Fights.' The Advertiser [Adelaide], 10 June 1986: 29. 
Diversity in Leadership: Australian women, past and present

New South Wales Task Force on Domestic Violence. Report of New South Wales Task Force on Domestic Violence to Hon $N$ K Wran QC, MP Premier of New South Wales. Sydney, July 1981, and follow-up report, 1985.

Optional Protocol to the Convention on the Elimination of All forms of Discrimination against Women. A/RES/54/4. New York: United Nations, 2000.

O'Sullivan, Kay. Trailblazers: The Road to Equality. Melbourne: Australia Postal Corporation, 2011. Pickering, Sharon and Caroline Lambert, eds. Global Issues, Women and Justice. Sydney: Sydney Institute of Criminology Series, 2004.

Ramsay, Janet. 'The Making of Domestic Violence Policy by the Australian Commonwealth Government and the Government of the State of New South Wales between 1970 and 1985: An Analytical Narrative of Feminist Policy Activism.' PhD dissertation, University of Sydney, 2006.

Sawer, Marian. 'The Long March through the Institutions: Women's Affairs under Fraser and Hawke.' Paper presented at the Australasian Political Studies Association 28th Annual Conference, Brisbane, 27-29 August 1986.

Sawer, Marian. Sisters in Suits. Sydney: Allen \& Unwin, 1990.

Sawer, Marian. Femocrats and Ecorats: Women's Policy Machinery in Australia, Canada and New Zealand. Geneva: United Nations Research Institute for Social Development, 1996.

Sawer, Marian. 'Disappearing Tricks.' Dialogue: Academy of the Social Sciences in Australia 27(3) (2008): 4.

Sawer, Marian. Making Women Count: A History of the Women's Electoral Lobby in Australia. Sydney: UNSW Press, 2008.

Sawer, Marian and Merrindahl Andrew. 'Hiding in Plain Sight.' In The Women's Movement in Protest, Institutions and the Internet: Australia in Transnational Perspective, edited by Sarah Maddison and Marian Sawer, 70-86. New York: Routledge, 2013.

Thomson, Peter. 'Elizabeth Evatt: Integrating Women's Issues in the United Nations Human Rights System.' In Australians at the United Nations, Unpublished ms. Canberra: Department of Foreign Affairs and Trade, [on file with the author], 1996.

Thornton, Margaret. 'Auditing the Sex Discrimination Act.' In Human Rights 2004: The Year in Review, edited by Marius Smith. Melbourne: Castan Centre for Human Rights Law, Monash University, 2005. 
Thornton, Margaret. 'Feminism and the Changing State: The Case of Sex Discrimination.' Australian Feminist Studies 21(50) (2006): 151-172. http:// www.informaworld.com/.

United Nations Beijing Conference on Women. Platform for Action and Final Report. New York: United Nations, 1995. http://www.un.org/womenwatch/ confer/beijing/reports/.

United Nations General Assembly. Resolution 48/104 of 20 December 1993. New York: United Nations, 1993.

United Nations Nairobi Conference on Women. Final Report. New York: United Nations, 1985. http://www.un.org/womenwatch/daw/beijing/ otherconferences/Nairobi/Nairobi\%20Full\%20Optimized.pdf.

United Nations Convention on the Elimination of All forms of Discrimination against Women. GA res. 34/180, 34 UN GAOR Supp. (No. 46) at 193, UN Doc. A/34/46; 1249 UNTS 13; 19 ILM 33. New York: United Nations, 1980.

West, Rosemary. 'Judging Women's Place in the World.' The Age, 10 May 1995: 21.

Women's Rights Action Network of Australia (WRANA). Australian NGO Shadow Report on the Implementation of CEDAW. 2005.

YWCA Australia. 'CEDAW National Action Plan.' 2011. http://ywca.org.au/ advocacy-policy/our-united-nations-work.

YWCA Australia and Women's Legal Services Australia. Australian NGO Shadow Report on the Implementation of CEDAW. 2009. 
This text taken from Diversity in Leadership: Australian women, past and present, edited by Joy Damousi, Kim Rubenstein and Mary Tomsic, published 2014 by ANU Press, The Australian National University, Canberra, Australia. 